\title{
Context, Content, and Composition: Questions of Intended Meaning and the Aśokan Edicts
}

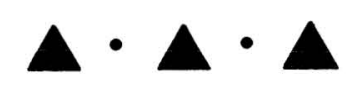

NAMITA SUGANDHI

Despite its Relatively SHORT SPAN, THE MAURyAn EMPIRE holds great significance for the modern Indian nation. Often celebrated as India's first empire, the Mauryan polity (c. 320-180 в.C.) is frequently held up as the emblem of an early national unity, although, as is the case with many ancient empires, much doubt still exists regarding the actual extent and nature of control exercised by Mauryan rulers. The central theme of this paper aims to work toward a resolution of this doubt by developing a critical and multidisciplinary understanding of the Aśokan edicts, a crucial category of evidence often used in the construction of Mauryan historical narratives.

Questioning the common understanding of these edicts as imperial boundary markers, this paper investigates issues of intention and audience by examining existing data about the archaeological context, historical content, and linguistic composition of a cluster of edicts found in the southern Deccan, an area far south of the Mauryan imperial heartland in the Ganga Valley. While the imperial status of the Mauryan polity is not denied here, this paper attempts to show how the use of a multidisciplinary approach and a combination of perspectives is valuable in re-opening the question of Mauryan imperial interaction in the Indian subcontinent.

\section{THE MAUYAN EMPIRE}

Numerous legends exist regarding the Mauryas; it is often difficult to distinguish historic fact from mythic fiction, but the most general details about this dynasty are well known and seldom disputed. As legend has it, the first of the Mauryan kings, Chandragupta Maurya, came to power in the state (janapada) of Magadha in the Ganga Valley in the fourth century B.C., supposedly with the aid of the Brahmin Chānakya or Kauțilya (R. Thapar 1997a:13). His expanding empire was inherited by his son Bindusāra who is reputed to have extended control to include most of India with the exception of the eastern state of Kalinga (part of

Namita Sugandhi is a Ph.D. candidate in the Department of Anthropology at the University of Chicago, Illinois.

Asian Perspectives, Vol. 42, No. 2 (1) 2003 by University of Hawai'i Press. 
modern-day Orissa) and the southernmost part of the peninsula (Bongard-Levin 1985:79-81; Chakravarti 1947-1948; R. Thapar 1997a:17-18).

It was under Bindusāra's son, Aśoka, that the Mauryan polity is alleged to have reached its greatest extent. It is said that after the crushing defeat of Kalinga, Aśoka, overcome by the suffering and destruction caused by his bloody conquest, vowed to end the imperial policy of military conquest and became intensely devoted to the practice of Buddhism (Bongard-Levin 1985:81-84). The Aśokan edicts, a series of stone inscriptions found as far north as Afghanistan and as far south as Karnataka and Andhra Pradesh, are seen not only as a testament to Aśoka's dedication to conquest by dharma (loosely translated as righteous deeds or morality) as opposed to military action, but as indicators of the boundaries of a practically pan-Indian empire (cf. Schwartzberg 1992:18). This fits in well with nationalist interpretations of Indian history that are anxious to portray the Indian subcontinent as a unified polity from the earliest of times, but in more recent years, the idea of a centralized, uniformly administered empire has fallen into serious doubt (e.g., Allchin 1995; Ray 1987, 1989, 1994; Seneviratne 1978, $1981: 62$ ), leaving questions about how exactly the distribution of these edicts should be understood and consequently, what relationship this dynasty had with parts of the Indian subcontinent beyond the Ganga Valley over time (Seneviratne 1981; Sinopoli 2001b). In many ways, these questions reflect a growing trend to subject earlier analyses of ancient polities to renewed scrutiny that is influenced not only by the critical restructuring of earlier state models, but also by the employment of a variety of multidisciplinary methodologies that are informed by more recent theoretical developments in the social sciences (Alcock et al. 2001).

Recent debates about the nature of empires have not only reformulated common definitions to allow for more flexibility but have also pointed to the way in which rigid pre-existing ideals, often predicated on models of Roman or modern European imperialism, can color the interpretation of a given polity dubbed "imperial" by various scholarly traditions (Alcock et al. 2001; Sinopoli $2001 b$ ). Given a very loose definition of an empire as an expansive state incorporating some degree of economic, political, religious, or ethnic diversity (Barfield 2001:29; Morrison 2001:3; R. Thapar 1987:1-2), it may not always be necessary to re-question the epistemological classification of a polity as "imperial." However, given this structural loosening of imperial definitions, it is now essential to revise some understandings of these empires by allowing this general flexibility to permeate into more particular historical narratives, in this case, that of the Mauryan empire.

This paper represents a beginning inquiry into this type of revision by reopening the question of Mauryan imperial interaction within the southern Deccan; a region lying far south of the original Mauryan state of Magadha. This is a response to the assertion that idealized views of empires as uniformly administered, geographically continuous, uncontested political units are rarely actualized despite possible elite or scholarly claims to the contrary. Previous studies have attempted to get around this sort of problem by characterizing the Mauryan empire in a number of different ways, for example, as a "galactic polity" (Tambiah 1976) or "metropolitan state" (R. Thapar 1981). However, these definitions often do little more than replace one type of (presumed) state structure with another and then impose that structure on a political and social landscape that is 
still poorly understood. It is difficult, if not impossible, to determine the physical geography of an imperial polity based solely on ideological claims.

In some sense then, it is more profitable to define the term "imperialism" as a process or strategy rather than to focus on "empire" as a territorial entity since the actual success of such strategies is often more an assumption than a given. Highlighting the deliberate and purposeful nature of policies implemented by ruling societies in the attempt to carry out and sustain imperialist projects, the question of imperial intention becomes crucial when examining the often problematic historical and archaeological evidence of the Mauryan empire.

There are many historic sources from which information about the Mauryan period is drawn, including the Purānas (legendary texts), the Arthaśāstra, fragments of the Greek Indika of Megasthenes, parts of the Pāli canon, legendary Avadana texts, and the Aśokan edicts. However, none of these sources is without its problems, particularly in terms of the chronology of their composition, their reliability as accurate records of existing conditions, and the potential biases of the authors (Bongard-Levin 1985:16-55).

When it comes to understanding administrative structure and state ideology, the two sources most frequently relied upon are the Arthaśästra and the edicts of Aśoka. Recently, assumptions based on uncritical readings of the Arthaśästra have been challenged (Fussman 1987-1988:46-48; Habib and Habib 1989-1990:5758; Trautmann 1971) due not only to uncertainties of dating but also because of its status as a prescriptive rather than descriptive political treatise (Morrison 1995:206-207). Keeping the limits of these other textual sources in mind, many scholars have turned to the Aśokan edicts - themselves, both text and monument (discussed below) - in order to discern the extent and nature of the Mauryan empire (Allchin 1995; R. Thapar 1997a). In many of these analyses, however, these inscriptions have been interpreted both as markers of imperial boundaries or territory and as clues to the administrative structure of the Mauryan polity. Given the absence of any other unambiguous material evidence of a Mauryan presence in such distant parts as the southern Deccan, closer examination of the edicts themselves seems called for. As discussed below, a closer analysis of the information contained within the edicts, in terms of archaeological context, textual content, and linguistic composition, makes it difficult to accept this kind of wholesale reliance on the edicts to describe the extent and nature of the Mauryan polity.

\section{THE AŚOKAN EDICTS}

Based on content and the materials on which they are inscribed, the Aśokan edicts are divided up into four main categories: major rock edicts (RE), minor rock edicts (MRE), major pillar edicts, and minor pillar edicts. Another category, known as the separate Kalinga rock edicts (SKRE), is found only in the region of the Kalinga state and at one location in the south. Most of these edicts are written in a Prākrit dialect in Brāhmī script. However, there are some inscriptions in the northwest that are in a Prākrit dialect in Karosțhi script or bilingual in Greek and Aramaic. Most of the rock edicts may be considered in situ as they are inscribed on immovable rock formations, although there is historical evidence that some of the pillar edicts have been moved. 
Table i. Chronology of the Rock Edicts Based on Statements about Their Regnal Year of Erection When Correlated with Absolute Dates of Aśoka's Rule

\begin{tabular}{lll}
\hline EDICT & DATE & YEAR OF AŚOKA'S RULE \\
\hline Minor rock edicts & c. 258 B.C. & Eleventh or twelfth \\
Major rock edicts & c. 257 B.C. & Twelfth or thirteenth \\
Pillar edicts & c. 243 B.C. & Twenty-sixth \\
\hline
\end{tabular}

(From Sen 1956)

The edicts are not difficult to place into a relative chronology, due to the fact that many state the regnal year of their erection (see Table 1). The actual texts of the edicts are highly redundant and are often designated by numbers (for example, major rock edicts I-XIV, minor rock edicts I and II).

While these edicts primarily detail moral reforms instituted by Aśoka and provide recommendations for leading a moral life according to dharma, many scholars have read into them over-determined details of administration and political organization (cf. Bongard-Levin 1985; Dikshitar 1932; Fussman 1987-88; R. Thapar $1997 a, 1997 b)$. Equally questionable is the practice of delimiting the extent of the Mauryan territory on the basis of edict locations (see Fig. 1).

The focus of this paper is on the southern Deccan region and versions of the major and minor rock edicts found there (see inset, Fig. 1). This region, which is far from both the core Mauryan territory and other groups of edicts found in the Indian subcontinent, contains a distinct cluster of sites with rock edicts. This has led to the prevailing assumption that the area was incorporated, in some form or another, into the Mauryan empire. Although a preliminary reading of the edicts may render this hypothesis quite credible, upon closer examination, such interpretations are somewhat difficult to sustain, due to the lack of any other evidence of a distinctly Mauryan presence in the area such as common ceramic types, punch-marked coins, or typically Mauryan art forms that are found in the north. This is particularly problematic when one considers that the edicts as a material expression of authority or influence may only have served as a claim to rather than a reflection of actual control or influence (Morrison and Lycett 1994).

\section{PROBLEMS AND PERSPECTIVES}

In developing a more nuanced understanding of the Aśokan edicts and, consequently, Mauryan imperial strategies and claims, it is essential to question previous interpretations and assumptions by inquiring about the intended meanings of these inscriptions when viewed as a possible demonstration of a deliberate imperialist project undertaken by Aśoka. In examining this intended meaning, a consideration of the intended audience is crucial, for not only does it emphasize the performative value of the edicts, it also provides a focus from which to articulate questions about archaeological context, historical content, and linguistic composition. 


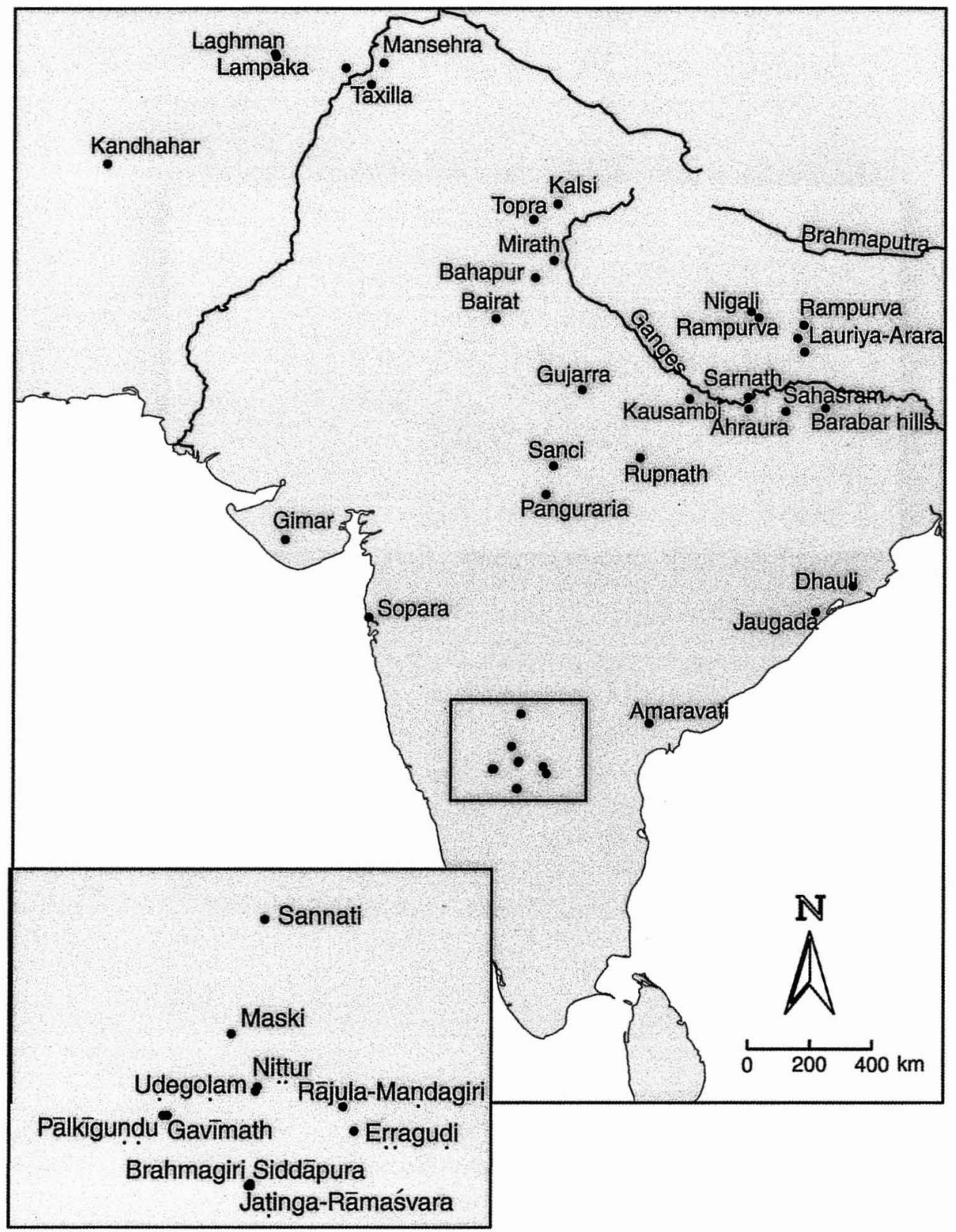

Fig. 1. Edict locations in the Indian subcontinent. Inset: edict locations in the southern Deccan.

The adoption of multiple perspectives in this paper represents something of a departure from many current approaches to the study of the ancient historic past. This approach frames questions that are bounded by three distinct disciplinary traditions, but then poses those questions to one particular category of evidence-the edicts. In some ways, this can be considered an inversion of other 
types of analysis, even those as explicitly multidisciplinary as many forms of historical archaeology or Annales history, which often espouse the use of multiple lines of evidence but do so within the confines of one specific discursive practice. Though this paper is similarly constrained to a certain extent in terms of its direct concerns, the examination of the edicts through a number of different disciplinary routes reveals how difference in discourse can affect the types of questions that are asked of available evidence. The argument here is that divergent inquiries can lead to divergent attempts at solution. The goal is to ultimately harness these discursive differences into one coherent whole that is able to simultaneously take into account the varying interpretations constructed by each perspective.

\section{CONTEXT}

In most cases, information about the archaeological context of the areas surrounding edicts is scarce. This problem is compounded by the fact that the chronology of this region is poorly understood and, to a large extent, still based on the work by Mortimer Wheeler done in the 1940s during his program of "opening up the south" (Wheeler 1949), which attempted to determine a chronology of South Indian prehistory and early history. Based on excavations at the sites of Arikamedu and Brahmagiri, Wheeler developed a three-tiered, overlapping cultural sequence, beginning with the "Stone Axe" culture, which was replaced by the "Megalithic" (Iron Age) and then "Andhra" cultures (Wheeler 1947-1948). The determination of these cultural periods was based largely on ceramic types; the Andhra culture was identified by ceramics such as Rouletted Ware (RW) and Russet-Coated Painted Ware (RCPW), which were found in association with Roman wares such as Terra Sigallata and amphorae (Wheeler 1947-1948).

Though some of the terms and almost all of the dates have been altered since the original publication of Wheeler's research, our understanding of the "southern Neolithic," "Iron Age," and "Early Historic" periods in the southern Deccan are still deeply rooted in Wheeler's original culture-historical model that saw one culture as being "replaced" by another; presumably through processes of diffusion. The mid-third century B.C. date of the edicts places their establishment in the southern Deccan sometime during the end of the "Iron Age," which, along with the Neolithic, continues to be pushed further and further back from Wheeler's original chronological scheme, due to continued excavation and the application of radiocarbon-dating techniques (Ghosh 1990:84).

In some ways, the time period of the edicts marks a transition between the Iron Age and Early Historic period in the south. However, the idea of such a transition period is complicated by the fact that scholars often place the beginning of the Early Historic period earlier in chronological designations of northern India (between 800 and 500 в.с.) than of southern India (between 500 and 200 B.c.). As can be seen from existing site reports, the Early Historic period in the Deccan, unlike the Early Historic period in northern India, is often thought to commence with the rise of the Sātavāhana dynasty in the first century B.c. A more conservative view of the southern chronology is adopted here (see Table 2). Identification of the South Indian Iron Age in the material record continues to be made primarily on the basis of ceramic typologies, most notably by the presence of Black-and-Red Ware (BRW) and the absence of Early Historic RW and 
Table 2. Suggested Absolute Chronology of the Neolithic, Iron Age, and Early Historic Periods in the Southern Deccan

\begin{tabular}{ll}
\hline PERIOD & \multicolumn{1}{c}{ DATES } \\
\hline Neolithic & c. $3000-1200$ B.C. \\
Iron Age & c. $1200-300$ B.C. \\
Early Historic & c. 300 B.C. - A.D. 300 \\
\hline
\end{tabular}

RCPW, though the dependence on ceramic typologies is equally problematic as (and in many ways related to) the use of culture-historic frameworks in the development of a chronological trajectory.

There are eleven sites in the southern Deccan area where edicts have been found. Located in the modern-day states of Andhra Pradesh and Karnataka, these sites are often considered together as a distinct cluster of edicts, though they can also be divided up into several groups according to proximity and stylistic similarity (see Table 3).

With the exception of Brahmagiri, Maski, and Sannati, little if any serious archaeological research has been carried out at the edict sites under discussion. However, some general details about surface features and edict placement are available and are useful in thinking about issues of context, audience, and visibility.

\section{Edict Sites}

Group 1 - The site of Errragudi is particularly interesting as it is the location of both minor rock edicts I and II as well as all fourteen of the major rock edicts. With the exception of Sannati, this is the only site in the south where the major rock edicts have been found. Furthermore, it is the only location where both the minor and major rock edicts occur. From this, one might conclude along with Sircar (1979) that the site was particularly important; some have identified it with

Table 3. Edicts of the Southern Deccan Grouped According to Modern District Division and Number and Type of Edicts Present

\begin{tabular}{|c|c|c|c|}
\hline GROUP & SITE & DISTRICT & EDICTS \\
\hline 1 & Erṛaguḍi & Kurnool (Andra Pradesh) & $\begin{array}{l}\text { RE I-XIV } \\
\text { MRE I, II }\end{array}$ \\
\hline 1 & Rājula-Maṇdagiri & Kurnool (Andra Pradesh) & MRE I, II \\
\hline 2 & Maski & Koppal (Karnataka, formerly Raichur) & MRE I \\
\hline 2 & Gavīmath & Koppal (Karnataka, formerly Raichur) & MRE I \\
\hline 2 & Pālkīgundu & Koppal (Karnataka, formerly Raichur) & MRE I \\
\hline 3 & Nițțur & Bellary (Karnataka) & MRE I, II \\
\hline 3 & Ụḍegolam & Bellary (Karnataka) & MRE I, II \\
\hline 4 & Brahmagiri & Chitradurga (Karnataka) & MRE I, II \\
\hline 4 & Siddāpura & Chitradurga (Karnataka) & MRE I, II \\
\hline 4 & Jaṭinga-Rāmeśvara & Chitradurga (Karnataka) & MRE I, II \\
\hline 5 & Sannati & Gulbarga (Karnataka) & $\begin{array}{l}\text { RE XII, XIV } \\
\text { SKRE I, II }\end{array}$ \\
\hline
\end{tabular}


the city of Suvarnagiri, often believed to be the southern provincial capital of the Mauryas (Sircar 1979:54). The Erragudi edicts are inscribed on six boulders in a low range of hills locally known as Yenakonda or Nallayenakonda (black elephant hillock) (Sircar 1979:1). Archaeological research at this site has been limited in scope; exploration in the area has yielded Lower and Middle Paleolithic tools (Ghosh 1990:469; IAR 1959-1960:11). Lithics were also found close to megaliths and Early Historic materials; besides Black-and-Red Ware and associated Red Polished Ware, no mention is made of any other remains, but even this cursory observation suggests the site had a relatively long occupation period (IAR 1959-1960:11).

The poorly preserved minor rock edicts at Rajjula-Mandagiri are found about $32 \mathrm{~km}$ from Erragudi (Sircar 1979:105). Sircar (1979:105) notes that the edicts are engraved on a rock upon which stands a Ramalingesvara temple and that four other early and medieval inscriptions were found in the area. These inscriptions are in Telugu and Kannada and date from the seventh and eighth centuries A.D. onwards (A. R. Ind. Ep. 1953-1954, appendix B). No other archaeological information exists for this site, but these brief notes suggest that this region has long had religious significance; though how far into the past that significance may be projected remains speculative. It is possible that this location was chosen for the establishment of an edict because of some pre-existing importance or, alternatively, that value was later given to the site because of the presence of one of Aśoka's inscriptions. Until more archaeological data contemporary with the edicts is available, it is impossible to say which of the two is more probable.

Group 2 - The minor rock edict found at Maski on a boulder at the entrance of a cavern (Allchin and Norman 1985:47; Sircar 1979:51-52) is significant in that it was the first edict found which mentioned the personal name of Aśoka (Patil and Patil 1998:34). In other previously known edicts, he is only referred to as Devanampiye (Beloved of the Gods) or Devanampiye piyadasin. It is only with the discovery of the edict at Maski that the king of the edicts came to be identified as the Aśoka of the Purānas and early Buddhist literature. Unlike most of the other sites in this discussion, there is a fair amount of information about Maski. Excavations have revealed evidence of occupation during the Chalcolithic, Megalithic (Iron Age), Early Historic, and Medieval cultural periods (B. Thapar 1957). Maski is usually described as having a Chalcolithic rather than a Neolithic period, but this distinction can be considered minor given the limited number of copper artifacts recovered, the long span of occupation, and the similarity of its remaining material culture to other sites in the region. The discovery of a large number of semiprecious beads from Chalcolithic contexts suggests that this area was engaged in long-distance trade from a very early period (B. Thapar 1957). Archaeological evidence from the Iron Age period includes burials, iron objects, and Black-andRed Ware (Ghosh 1990:282; B. Thapar 1957). Although no structures were found in the Iron Age levels, the detection of postholes suggests the presence of wooden buildings at the time (B. Thapar 1957:15). Frequently mentioned as a gold-rich area, Maski, like Errragudi has also been suggested as the location of Suvarnagiri “Golden Mountain” (B. Thapar 1957:10-11; Sircar 1979:55), though again, in the absence of any determinate evidence, it is difficult to assign ancient place names to modern-day sites. 
There is no published archaeological information about the outcrop where the Gavimath rock edict is located, though some scatters of Black-and-Red Ware have been noted (Morrison, pers. comm. 2002). The site is about a $1.5 \mathrm{~km}$ east of the town and fort of Koppal where some Neolithic Gray Ware, similar to that of Maski, was found along with chert blades and Megalithic (Iron Age) Black-andRed Ware (Allchin and Norman 1985 : 47). Although the edict here and at Pālkīgundu have been placed in the same group as the edict at Maski, the relatively great distance of these two sites from Maski (when contrasted with the proximity of other related sites) makes this grouping somewhat arbitrary. Although all lie within the same modern administrative district, their categorization is bascd on the common presence of only one minor rock edict, and the similarity of the material culture at Maski and Koppal.

The edict found in a cave on top of a hill at Pālkīgundu lies slightly more than a kilometer from Koppal and about $3 \mathrm{~km}$ from Gavimath (Allchin and Norman 1985:47). No details of any archaeological materials are currently available but the site's proximity to Koppal suggests that this area was perhaps known to the Iron Age inhabitants of the town.

Group 3 - The minor rock edicts found at Nittur are inscribed on two boulders at the foot of a hill range known as Sukradappana-gudda (Ghosh 1990:318; Sircar $1979: 123)$. In addition to Neolithic artifacts, there are some megalithic stone circles about $100 \mathrm{~m}$ to the south of the edicts, a few megalithic pit burials similar to those seen at Maski, and some circular alignments at the top of the hill (Ghosh 1990:318). The site lies about $5 \mathrm{~km}$ northwest of the site of Tekkalakota (Allchin and Norman 1985:47), which shows evidence of occupation from the Neolithic to Early Historic times (IAR 1963-1964:24-25). Although Tekkalakota is primarily known as an extensive Neolithic site, a significantly large scatter of Iron Age and Early Historic ceramics at the foot of one of the outcrops in the area suggests that this site continued to be extensively occupied into later periods (Nagaraja Rao and Malhotra 1965).

The site of Udegolam is about $5 \mathrm{~km}$ southwest of Nițtur and $8 \mathrm{~km}$ west of Tekkalakota (Allchin and Norman 1985:47; Sircar 1979:129). A survey of the area noted that Udegolam was a site of the Early Historic period (IAR 19621963:16), but no further details were made available. The survey also found evidence of Neolithic-Chalcolithic sites as well as megalithic and other Early Historic sites in the surrounding region (IAR 1962-1963:16), though it is clear that the area immediately adjacent to the edict was not part of a settlement (personal observation).

Group 4 - Out of all the sites under consideration here, it is perhaps Brahmagiri that has received the most archaeological attention. First investigated by the Mysore Archaeology Department in 1930 (Mysore Archaeological Department 1934), the site was later excavated by M. H. Krishna in 1940 (Ghosh 1990:82) and then by R.E.M. Wheeler. The Brahmagiri edicts are found inscribed on a rock at the foot of a hill at a short distance from an extensive area with evidence for Neolithic, Iron Age, and Early Historic occupation (Allchin and Norman 1985:47). The site of the Siddāpura edicts lies less than a kilometer from the Brahmagiri edict (Allchin and Norman 1985:47) and has been tentatively identified as the town site of Isilā, which is mentioned along with Suvarnagiri in the first 
minor rock edict in this group (Mysore Archaeological Department 1934; Sircar 1979:54). These edicts are inscribed on a ledge some way up a rocky group of hills (Hultzsch 1969:xxvii). About $4.5 \mathrm{~km}$ north of those hills are the edicts of Jaținga-Rāmeśvara (Allchin and Norman 1985:47; Hultzsch 1969:xxvii). The inscriptions are carved on an irregular slanting horizontal surface that is immediately in front of a flight of steps leading up to the medieval Jatinga-Rāmeśvara temple (Hultzsch 1969:xxvii).

Group 5 - The inscriptions found at Sannati are unique for a number of reasons. They were discovered in 1989 in the Chandralamba temple complex (Norman 1991). During the renovation of a shrine in the complex, the edicts were discovered on a slab that served as the base of a medieval image. The inscriptions contain the remains of major rock edicts XII and XIV as well as fragments of both separate Kalinga rock edicts (Howell et al. 1995:30; Norman 1991:101-102). The SKREs had previously only been found in the region of Kalinga at Dhauli and Jaugada in place of major rock edicts XI, XII, and XIII. Unlike other edict slabs found at Sopara and in Afghanistan, the edicts at Sannati are carved on both sides, proving that the slab was free-standing at the time of engraving (Howell et al. 1995:30; Norman 1991:102).

Because the edicts are carved on a cut slab rather than an immovable rock formation, it cannot be determined if these edicts were established somewhere in the immediate region or were brought from a more distant location at some point in time. The presence of edicts otherwise only known to the Kalinga region might suggest the latter, but there can be little certainty about this. The site of Sannati is an Early Historic period city enclosed within a brick fortification wall dated to the Sātavāhana period and there are a number of other sites, mostly Buddhist stupa mounds, in the surrounding area, as well as remains from Palaeolithic, Mesolithic, and Neolithic periods (Devaraj and Talwar 1996:2-5; Howell et al. 1995:1-3; Sundara $1986-87: 22)$.

\section{Discussion}

Despite the sparse nature of extant contextual information, there are a few observable trends that are of help in examining the potential audience of these edicts. The first is the close proximity of many of these sites to one another and evidence of their relatively long occupation periods, often from the Neolithic through the Early Historic or Medieval periods (Ghosh 1990; IAR 1962-1963, 1963-1964, 1966-1967, 1968-1969). Many of the locations of edicts were in or near substantial settlements (Maski, Brahmagiri, and Sannati) while others (e.g., Nițtur, Udegolam) seem to lie at some distance from any nucleated settlement. As Parasher suggests (1992), it is possible that the long span of occupation at many of these sites might indicate that they served as centers of some enduring economic, social, or political power that attracted the attention of Mauryan authority and became locations from which that authority asserted its presence in the area. This may very well be the case, but beyond speculation about the location of Suvarnagiri (Golden Mountain) and mention of gold-working sites around the area of Maski, there has been little effort made to detect any actual motive for Mauryan expansion or presence in the region. 
Reasons for the poor archaeological understanding of the Mauryas in the Deccan are numerous. A significant dilemma is the preoccupation of many archaeologists with earlier "prehistoric periods" in this region. This is demonstrated in site reports where evidence for Iron Age, Early Historic, or Medieval occupation is seen as an "intrusion" or unimportant to research objectives (e.g., IAR 19631964:24-25; Wheeler 1947-1948). The uncertain chronology and considerable overlap between variously defined periods, especially periods that are still largely based on culture-historical models and few radiometric absolute dates, has perhaps also contributed to the distortion of knowledge about different sites during different time periods.

Another possible explanation of a more political nature has to do with the relationship of northern and southern Indian cultural and scholarly traditions and the differences in terminology between the two. As mentioned previously, many reports define the Early Historic period on the basis of archaeological sites dating to the (post-Mauryan) Sātavāhana period. While the Mauryan period is more often associated with the very end of the Iron Age during the transition to the Early Historic in the south, it falls squarely within conventional chronological definitions of the Early Historic in the north (Allchin 1995). Although there may be a number of reasons for this difference, the seeming neglect of the Mauryas in South Indian scholarly traditions may be attributed to their status as northern invaders in models of military conquest and "empire," unlike the autochthonous Sātavāhanas who originated in either the Andhra or Maharashtra region.

As previously mentioned, one of the most pertinent problems in delineating the nature and extent of the Mauryan polity is the difficulty in archaeologically identifying a Mauryan presence. Although the presence of the ceramic type known as Northern Black Polished Ware (NBP) was once thought to be an indication of a Mauryan presence, the extent of its distribution in both space and time now renders that assumption untenable, particularly in the north where this has often been a common supposition (Mishra 1989). Even if the presence of NBP was still thought to indicate contact with the Mauryas, there are very few sites in South India where evidence of this pottery is found. Some finds of NBP have been reported at Sannati (Devaraj and Talwar 1996:9), but the nature of the edict found at Sannati makes this an unreliable source for any assumptions about the relationship between NBP, the edicts, and Mauryan interaction in the south. Similarly, punch-marked coins associated with the Mauryas are quite rare in the southern Deccan. In most cases, the only existing archaeological evidence of a specifically Mauryan presence in the south is the Aśokan edicts themselves.

In questioning the intended audience of these edicts by examining archaeological context, the visibility of the edicts is an important consideration. The location of many of these edicts in caves or on boulders on a hill is curious. This has often been interpreted with the explanation that edicts were established not only in towns and cities but along common transportation routes as well. While some studies have been done on potential trade routes and resource-rich areas (Lahiri 1992), this research is still not detailed enough to allow analysis at the scale required to sustain this kind of interpretation for the southern Deccan.

As noted, it appears in many cases that edicts were placed at some distance from a known settlement. At places such as Rājula-Mandagiri it is not even clear whether or not a settlement existed nearby the established edicts. The interpreta- 
tion of such contexts is quite problematic. Were these sites the location of some sort of poorly preserved social space related to nearby towns, or were such edicts deliberately placed in out-of-the-way locations in order to establish some kind of covert claim to the surrounding landscape?

\section{CONTENT}

Unlike the archaeological context, the actual texts of the edicts have received a considerable amount of attention since their decipherment by James Prinsep in 1837. Numerous translations have appeared over the last century or so, some of the most notable being those of Smith (1901), Bloch (1950), Sen (1956), Nikam and McKeon (1959), Hultzsche (1969), and Sircar (1979). A close examination of this scholarship shows how the view of Aśoka as a great Buddhist philosopher king or the idea of the Mauryan period as representative of an Indian "golden age" has often been inserted into many of these translations. This sometimes unconscious bias has frequently had the effect of distorting our understanding of the type of information actually contained in these inscriptions. For example, one may consider the contrast between Smith's translation of RE III and a more literal reading:

Thus saith his Majesty King Priyadarsin:-

In the thirteenth year of my reign I issued this command:-

Everywhere in my dominions the lieges, and the Commissioners, and the District Officers must every five years repair to the General Assembly, for the special purpose, in addition to other business, of proclaiming the Law of Piety, to wit, 'Obedience to father and mother is good; liberality to friends, acquaintances, relatives, Brahmans, and ascetics is good; respect for the sacredness of life is good; avoidance of extravagance and violence of language is good.' The clergy will thus instruct the lieges in detail, both according to the letter and the spirit. (Smith 1901:116-117)

The Beloved of the Gods King Priyadarśi thus said: This has been ordered by me [who is] annointed for twelve years. Everywhere in my territory every five years let the Yuktas, Rájukas and Pradesikas go out traversing [the land] for the purpose of this dharma instruction and also for other work. Obedience to mother and father is good. Giving to friends, acquaintances, relatives, ascetics, and Brahmins is good. The nonkilling of beings is good. Small extravagance and small possessions is good. And the assembly will also appoint the Yuktas in registering with [a] reason and according to the letter. (text from Andersen 1990; translation mine)

In many ways, the latter text has been undertranslated in the sense that it has been purposely kept unembellished in any way. However, this type of literal reading well demonstrates the way in which the edicts are often overtranslated, giving the edicts and Aśoka's voice a grandiosity which is quite simply not there. This in turn has led to an overinterpretation of the types of information actually contained in the edicts.

The main issues focused on here are the details of territorial control and administrative organization that are often extracted from translations of the edicts. A closer examination of a literal translation reveals that there is not always as much overt political content in the edicts as one might believe, though there are some valuable details that deserve mention.

Of particular importance is the list of kings living beyond the Yona (Greek) king Antiyoga (identified as Antiochus II, Theos of Syria; also mentioned in RE 
II) in RE XIII; Tulamāya (Ptolemy II, Philadelphus of Egypt), Antekina (Antigonus Gonatas of Macedonia), Makā (Magas of Cyrene), and Alikasudara (either Alexander of Corinth or Alexander of Epirus) (Hultzsche 1969:48; R. Thapar 1997a:40-41). In addition to adding an element of historical reality to the edicts and demonstrating Mauryan contact with or knowledge of the Hellenic world, the ability to externally date these kings has made major rock edict XIII one of the most significant anchors of ancient Indian chronology.

Another important aspect of these edicts include references to the Colas, Pāndyas, Satiyaputras, and the Keralaputras; people living on the borders (pracamta) of Aśoka's domain (RE II, V, and XIII). It is also interesting that in RE XIII, after naming people on the borders, Aśoka names a number of other groups as lajavisavasi (in the settlement of the king). A literal translation of this statement has led to the common assumption that the Mauryas exercised some form of sovereignty over these groups and hence, their territory. However, it needs to be recognized that in this particular edict, Aśoka does not make reference to any form of political or military control whatsoever but rather his policy of conquest by dharma. In fact, the main subject of RE XIII is Aśoka's regret about the Kalinga war in the eighth year of his reign and his commitment to the policy of conquest by dharma.

... This is thought by the Beloved of the Gods to be the best conquest-that is the dharma conquest. That again is obtained by the Beloved of the Gods here and among the borders even as far as six hundred yojanas where there is the Yona king called Antiochus and also beyond that Antiochus the four kings called Tulamāya, Antekina, Makā, and Alikasudara and also below, the Colas, Pāndyas up to Tambraparni and in the same way, here in the king's settlement among the Yonas, Kambojas, Nabhakas, Nabhapamtisus, Bhojas, Pitinikas, Andhras, and Paradas-everywhere they follow the dharma instruction of the Beloved of the Gods. Even where the messengers of the Beloved of the Gods do not go they, having heard of the dharma speech, practice and dharma instruction of the Beloved of the Gods, act in conformity with dharma and will follow [it]. Everywhere this conquest is obtained by this way - in every way there is a feeling of joy. This joy is obtained in the dharma conquest ... (portion of Erragaudi RE XIII, text from Sircar 1979; translation mine)

But what exactly does Aśoka mean by "dharma conquest"? From statements made in RE XIII, Aśoka claims to have won this conquest not only in his own domain but also among all his borderers even as far as the kingdoms of the four kings mentioned above and as far south as Tâmraparnī (identified as Sri Lanka). This is a strong claim and it is most certain that Aśoka did not wield much political clout in some of these regions. So what exactly would such a conquest consist of?

In MRE I, Aśoka proclaims his stronger commitment to the Buddhist Sangha (assembly) and states that he has made this edict so that lowly and great persons would similarly practice such "zeal" (Sen 1956:52) and that also the people living on the borders (amtā) would know of it. Components to the practice of dharma are given in MRE II and REs III, IV, IX, XI, and include obedience to parents and elders, kindness toward and the non-killing of living beings, truthful speech, giving to friends, acquaintances, relatives, Brahmins and ascetics, and limited (small) extravagance and possessions.

These are noble ideals but also very general ones. To expect these principles to be consciously adhered to by a majority of the population would represent a gross 
naiveté on the part of any ruler. Perhaps this was realized by Aśoka because in many edicts, there is mention of specific officers appointed to carry out his orders. It is from these references that many have deduced details of Mauryan political administration.

The most commonly mentioned officers in the edicts are the Mahāmātrās. The term also occurs in the Arthaśástra and is used in a general sense to designate a high official (Kangle 1965:194). In the edicts, the term is sometimes used generally but is most often given a more specific sense such as the ithījhakamahāmātrā "officer who keeps an eye on women" (RE XII) or Mahāmātānagalaviyohālaka "city officer of judicial affairs" (SKRE I). The Mahāmattrā that is spoken of most often in the edicts is, not surprisingly, the dhammamahamata ("dharma officers"), which Aśoka states he appointed in the thirteenth year of his reign (interestingly enough, after the MREs are supposed to have been established) to move through all segments of the population for the purpose of establishing and propagating dharma (RE V). Other officials mentioned include the Yuktas, Rajukas, and Pradesikas who were to tour everywhere in Mauryan territory (sarvata vijite) for the purpose of dharma instruction (RE III).

It is quite clear that while Aśoka may mention several types of officials in his edicts, there are not very many references to their service in terms of administration but rather in terms of their duty of spreading and perhaps, maintaining, Aśoka's policy of dharma. An exception to this is some references made about the handling and release of prisoners (RE V and SKRE I). However, even in this context, the subject is on the proper (i.e., moral) behavior to be followed by the officers. Actual historical speculation about administrative organization during the Mauryan period has primarily relied on evidence from the Arthaśāstra or the writings of Megasthenes (cf. R. Thapar 1997a:94-136) which can inflate the meanings of terms found in the edicts.

Even the commonly accepted division of the Mauryan polity into provinces with capitals at Taxila, Ujjain, Tosalī (Dhauli), and Suvarṇagiri, though plausible and often employed, are based on unquestioned details from the edicts. Mention is made in the SKRE I of Mahāmātrās being sent out from Tosalī, and then later in the edict, it is said that princes (Kumāle) from Ujjain and Taxila will also send out Mahāmātrās every five years. MRE I found at Brahmagiri, Siddāpura, and JațingaRāmeśvara (Group 4) start with "From Suvarnagiri by the words of the Aryaputra and Mahāmātrās. Good health is to be told to the Mahāmātrās at Isilā." "These princes (aryaputra) are often assumed to be the viceroys of the north, south, east, and west provinces (R. Thapar 1997a:100) but Fussman (1987-1988:61) questions this rather neat division of the "empire" by mentioning the MRE found at Pāngurāriā that mentions another kumara but not a place of residence and suggests that there could be others mentioned as well that have not been discovered. This, too, is a valid hypothesis, however the point here is not to prove one or the other true or false but rather to demonstrate the way in which the simply stated edicts have been read into for the purpose of supplying political and administrative information about the Mauryan period.

However, what cannot be contested is the propagandistic nature of the edicts. The sixth RE is an interesting one in which Aśoka declares his commitment to the affairs of the people. A comparison is often made between this edict and statements in the Arthaśästra that a king should not be difficult to access and 
should hear at once every urgent matter (Arthaśästra 1.19.26 and 1.19.30). Much is also made of his statement in the SKRE that "all men are my children." These are both rather general statements however, and could perhaps be issued by any sovereign as an overt political message justifying his claims to rule. A list of Aśoka's personal qualities that are mentioned in the edicts could go on almost indefinitely. But how should the audience of these messages be understood?

In answering this, the actual content of the edicts is helpful because it is possible to examine statements of both direct and indirect address in the text and pose questions about the nature of the intended audience. It is interesting to note that of the edicts found in the southern Deccan, it is only the second minor rock edict and both of the separate Kalinga rock edicts that contain a direct statement of address in terms of the use of the second person plural. In these statements it appears as if Aśoka is speaking to particular officers; the Mahāmātrās in the case of the separate rock edicts and another official, a Rajuka, in the second minor rock edict.

The Beloved of the Gods said thus - What the Beloved of the Gods said-this is to be done. The Rajuka is to be commanded. Now he will command the country people and the Rastrikas: Mother and Father are to be obeyed and thus elders are to be respected. Beings are to be sympathized with. Truth is to be spoken. These dharma qualities are to be practiced. Thus you are to command with the words of the Beloved of the Gods. Thus you are to command the elephant riders, the scribes, the charioteers, and the Brahmins. Thus you are to instruct pupils in which[ever] ancient practice. This is to be obeyed. What honor is of a teacher is therefore this. And accordingly it is to be practiced appropriately [by] the relatives of the teacher among the female relatives. ${ }^{2}$ Also this is to be appropriately practiced among pupils - that which is the ancient practice. Thus you are to appropriately command and instruct pupils so that this might be excessive [be more?]. Thus commands the Beloved of the Gods. (Errragudi MRE II, text from Andersen 1990; translation mine)

Despite the lack of such a direct address in the other edicts, it is still possible to understand how the message of the edicts could have been meant for a more public audience; particularly from commands in the separate rock edicts that they are to be listened to (sotaviya), instructions for the Rajuka to preach (command) the qualities of dharma to the country people (janapad[e]), elephant riders, scribes, charioteers, and Brahmins (MRE II), and reasons for their announcement (savane savite); so that all people, including those on the borders, may know of and practice dharma (MRE I).

In general however, it seems as if the actual text of the edicts was more specifically directed toward those who had some sort of close relationship with Aśoka and the Mauryan polity. This is particularly seen in explanations for the reason of the edicts, so that the descendents of Asoka will continue to follow, increase and teach dharma (RE IV, V, VI) and not engage in violent and harsh military conquest (RE XIII), so that the city judicial officers might act rightly in the treatment of prisoners (SKRE I), and so that the Mahāmātrās will work toward the reassurance and practice of dharma among the borderers (SKRE II).

A look at statements of address in the edicts suggest that the message of the edicts themselves was largely directed toward particular officials but that Aśoka meant for a larger segment of the population to be made aware of their content either through the public reading of the inscriptions or by a more general 
instruction by Aśoka's dharma officers. But how can the role of the various officers mentioned in the different edicts be understood? Did they in fact hold some sort of position in Mauryan political administration or did they serve only in a missionary or social capacity without any kind of ruling authority? Additionally, the idea of these edicts as part of an imperial strategy of missionization to facilitate imperial incorporation (whether actualized or not) is an important one which certainly warrants future exploration. This is particularly important when considering how these edicts do not always seem to be situated in the most central or obvious of places in terms of contemporary occupation- not only are some edicts situated away from large settlements, but some are also hidden or sheltered within caves or under rock overhangs.

The issue of audience is also one that can be approached by examining the language of the edicts. Consideration of the linguistic composition is also important because it has a considerable bearing on modern translations and understandings of the edicts. Because many specific political and social entities have been translated by reference to other ancient texts, it is important to realize what has been defined by convention and to reassess what happens when some of those conventions fall under critical scrutiny. In this, it is language that becomes a crucial component of study, not only in terms of the actual translation but also because of the way in which the study of Sanskrit and Prākrit languages is often approached via an examination of ancient texts and the conventions of translation that are based on them. Thus, the discussion now shifts to questions of comprehension, not only of the people living during Mauryan times who may not have been familiar with the language of the edicts, but also of scholars working today.

\section{COMPOSITION}

In considering the linguistic composition of the edicts, it should be noted first of all that the Prākrit language of most of the edicts is Magadhi, a dialect that originated in the region of Magadha, the core area of the Mauryas and often assumed to be the administrative language of the Mauryan polity (Norman 1980). All edicts found in the south are in some form of Magadhi and written in the Brāhmī script. Variations in the language are seen in the edicts at different regions of the subcontinent and are commonly assumed to represent variation in local dialect. ${ }^{3}$ The use of Magadhi dialect in the south is particularly interesting. Regardless of any linguistic adjustments that may have been made in the southern Deccan edicts, the language is still one related to the Sanskrit and Prākrits of the north and, as Norman (1991:103) points out, it was most likely not the language used by the people of that region which was, as today, probably Dravidian. If the edicts were addressed particularly to Mauryan officers it is perhaps understandable, but if they were to be read out loud to the public, one would have to assume they were translated into the local vernacular before their message could be understood. Given this disjunction in language, it is curious that the use of Magadhi in the edicts has never been closely questioned.

Although archaeological research at Anuradhapura in Sri Lanka has revealed strong evidence for the use of Brāhmī script (on ceramics) from at least the fourth century B.C. (Coningham 1999; Coningham et al. 1996; Deraniyagala 1992), the development and spread of this script is still poorly understood. While most early 
Brāhmī inscriptions in the south (such as in Tamil Nadu, which is far south of the cluster of inscriptions discussed here) are written in a form of Tamil, it is interesting to note that reports of the Anuradhapura sherds state that the language of these particular inscriptions is in a form of Prākrit (Coningham et al. 1996:83, 92; Deraniyagala 1992:745-746). The implications of the use of this language-and the Brāhmī script in general-in pre- or contemporary Mauryan periods in the south may certainly be of significance and surely invites further study. By and large however, the edicts are often considered some of the earliest decipherable inscriptions found on the Indian subcontinent and they are at present the only texts of this period to be found in Karnataka and Andhra Pradesh.

Given the evidence of Brāhmī at sites far south from the area under consideration, the use of Brāhmī and the Magadha dialect in the edicts of the southern Deccan is somewhat understandable but nevertheless, rather curious. Even more so is the end of the second minor rock edict in Group 4 (Brahmagiri, Siddāpura, Jaținga-Rāmeśvara), which is signed, "written by the scribe Chapada" in Karostthi script though the rest of the edicts are in Brāhmī. While this phrase is too small and simple (Chapadena likhite li[pi]karena) to indicate any variation in dialect from the rest of the inscription, evidently, the body of the text was written in the script thought appropriate to that area and was not the language or dialect of the scribe who probably came from the northwest where Karosțhi was used. This example is often used to support the view that the edicts were written in the language thought most appropriate to the region (although it is not certain under whose initiative this was done) and also raises many issues about the transmission of the edicts (Andersen 1986, 1991; Falk 1993).

Overall, it must be noted that, in many cases, the major and minor rock edicts do not seem to be very carefully executed, particularly when compared with the later pillar edicts, as well as other inscriptions from subsequent time periods. This is seen both in terms of their composition and their engraving, from random mistakes in grammar and script to uneven lines of writing and the use of crudely inscribed characters (see Fig. 2).

Given the short span of time between the first certain appearance of Brāhmī script in Sri Lanka around the fourth century B.C. and the date of the edicts, are we to understand their apparent imperfections as an indication of the state of the development of writing and public monumentality during that time? This is a particularly vexing question when contrasting the rock edicts with the later pillar edicts, which are much more finely executed and definitely possess a monumental quality. As there is hardly fifteen years separating the rock and pillar edicts, should we assume that the development of public inscription underwent a rapid transformation during Aśoka's later years or is there perhaps some other explanation for the poor quality of the rock edicts?

Contemplation of this issue brings the discussion full circle back to the concept of context and visibility. Is there perhaps some relationship between poor execution and poor visibility? After all, if an edict was not really meant to be seen by a general public then it seems logical that less effort might have been put into its establishment. Similarly, it is also possible that the legibility of these inscriptions was not as important as the fact of their mere presence. Although this hypothesis does little to address those instances of overall poor visibility, it is possible that other markers existed to draw attention to the inscriptions but did not survive the passage of time. 


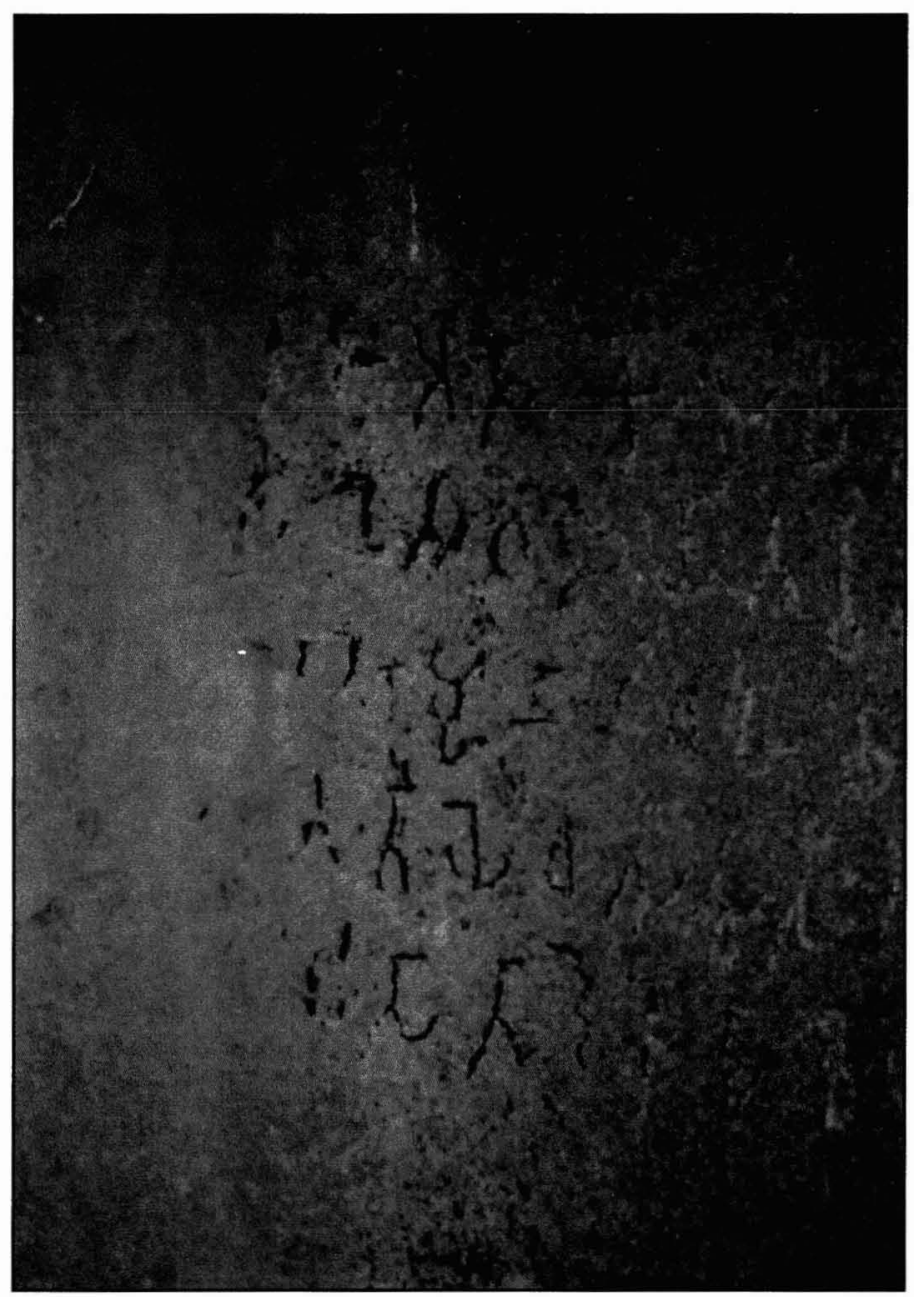

Fig. 2. Line from minor rock edict II at Nițtur, Bellary District (Karnataka).

\section{CONCLUSION}

In taking some preliminary steps toward a new approach in Mauryan studies, this paper has perhaps raised more questions than it has been able to answer. Without directly challenging the classification of the Mauryan polity as an imperial one, it is still possible to contest previously assumed imperial relationships by employing a more loosely structured definition of empire and focusing more on strategies that imply assertions of authority rather than assumptions of actual control.

Though the most current interpretations of the edicts have undermined previously held hypotheses of their ability to clearly delineate the extent and nature of the Mauryan polity, the edicts still have much to offer as a category of evidence, particularly in contexts such as the southern Deccan, where there is little else to suggest a Mauryan presence. What is now needed, in addition to further archaeological study, is both a finer tuning of the questions asked of the edicts along with a critically widened scope of interpretation. 
While this proposed method may seem somewhat paradoxical, this paper has tried to demonstrate how approaching the question of intended meaning through a variety of different disciplinary perspectives, can lead in turn to multiple questions about intended audience in terms of visibility, address, and comprehension. It remains now to begin some attempt to amalgamate these divergent questions into a more uniform analysis.

Beginning with the question of context and visibility, it has been noted that many edict sites seem placed in rather inconvenient locations-inside small caves or on unassuming boulders either at the base or top of some rocky outcrop. The suggestion that these edicts were deliberately placed in isolated areas as some kind of clandestine declaration of sovereignty is only partially defensible. Though some edicts are not found in the immediate vicinity of known occupied sites, neither were they randomly scattered throughout an empty landscape. The presence of relatively large settlements within reasonable range of many of the edicts may indicate that these edict locations were deliberately chosen and directed toward communities in these nearby settlements.

The hypothesis that the edicts in the southern Deccan were meant to be known to local inhabitants is supported by careful analysis of the content of the edicts and their use of address. While many of the edicts seem to be directed specifically to various categories of officials, Aśoka's many injunctions to spread the message of his edicts throughout all parts of society suggest that these inscriptions were not meant as furtive pronouncements and were in fact intended for a public audience in some way or another.

The extent to which this message was actually comprehended by communities in the region remains a debatable point. An examination of composition shows that the language of these edicts was a northern Sanskrit-based dialect. How widespread the use of Magadhi was in the southern Deccan is currently unknown but the assumption is that it was not very common. If representatives of the Mauryan polity were present in the area, it is possible that these edicts were translated by them and thereby made comprehensible to the general public. In the absence of any other known writing in the southern Deccan during this time period, one might presume that the edicts were written in Magadhi because the option of inscribing them in the local dialect simply did not exist.

The question of comprehension can also be posed in another light, not in terms of literal understanding but in the potential reception of Aśoka's message. How did the people of the southern Deccan interpret this message? Were these propagandistic statements meant to be read as a justification for the imposition of an alien sovereignty or as a plea to maintain peaceful yet autonomous relations? Until further research is conducted, this particular inquiry must necessarily end here, but a tentative suggestion is that the answer to this question may lie somewhere in between.

Similar to the way in which such investigations must sometimes remain openended until further research can be done, so too should the methodologies used to examine such questions maintain a certain amount of elasticity. There is always more than one way. The employment of a multidisciplinary approach should not be limited to just one single strategy or perspective; to do so would be antithetical to the principles of such studies in the first place. It would be imprudent to abandon the effort of any one discourse when it cannot determine the full story. Nei- 
ther should particular forms of evidence be discarded because they do not tell one precisely what one wants to know or imply exactly what one wishes to hear.

\section{NOTES}

1. Fussman explains this line by suggesting that it was a mistake on the part of the officer in charge of the engraving who included the dispatch letter as well (1987-1988:61). This line is only found at these three sites in the southern Deccan and can also be cited as supporting evidence that the edicts in the south are in fact attributable to Aśoka and not merely imitations sponsored by local elites.

2. The translation of this phrase is troublesome.

3. The use of Karosthi script as well as Aramaic and Greek in the northwestern edicts is also significant in this regard.

\section{REFERENCES CITED}

Alcock, S., T. D’Altroy, K. Morrison, and C. Sinopoli, eds.

2001 Empires. New York: Cambridge University Press.

Allchin, F. R.

1995 The Archaeology of Early Historic South Asia: The Emergence of Cities and States. Cambridge: Cambridge University Press.

Allchin, F. R., AND K. R. Norman

1985 Guide to the Asokan inscriptions. South Asian Studies 1:43-50.

ANDERSON, P. K.

1986 Preliminaries to a textual criticism of the minor rock edicts of Aśoka, in Deyadharma Studies in Memory of Dr. D. C. Sircar: 1-7, ed. G. Bhattacharya. Delhi: Sri Satguru Publications.

1990 Studies in the Minor Rock Edicts of Aśoka I: Critical Edition. Freiburg: Hedwig Falk.

1991 Notes on the engraving procedures for the Erragudi version of Aśoka's minor rock edict. Indo-Iranian Journal 34:267-276.

$A R$

1934 Annual Report of the Mysore Archaeological Department for the Year 1930. Bangalore: Government Press.

A. R. IND. EP.

1958 Annual Report on Indian Epigraphy 1953-54. Calcutta: Government of India Press.

BARFIELD, T. J.

2001 The shadow empires: Imperial state formation along the Chinese-Nomad frontier, in Empires: 10-41, ed. S. Alcock et al. Cambridge: Cambridge University Press.

BLOCH, J.

1950 Les Inscriptions d'Asoka: Traduites et Commentées. Collection Émile Senart, vol. 8. Paris: Société d'Édition "Les Belles Lettres."

Bongard-Levin, G. M.

1985 Mauryan India. New Delhi: Sterling Publishers Private Limited.

Chakravarti, N. P.

1947- The minor rock-edicts of Aśoka and some connected problems. Ancient India: Bulletin of 1948 the Archaeological Survey of India 4:14-25.

Coningham, R.

1999 Anuradhapura. The British-Sri Lankan Excavations at Anuradhapura Salgaha Watta 2. BAR International Series 824. Oxford.

Coningham, R., F. R. Allchin, C. Bath, and D. Lucy

1996 Passage to India? Anuradhapura and the early use of the Brahmi script. Cambridge Archaeological Journal 6(1): 73-97.

DERANiYAGala, S. U.

1992 Radiometric dating of early Brahmi script in Sri Lanka: 600-500 B.C., Addendum III, in The Prehistory of Sri Lanka, vol. 2:739-750. Colombo: Department of Archaeological Survey, Government of Sri Lanka. 
Devaraj, D. V., and H. T. Talwar

1996 Interim Report on the Excavations at Sannati, 1993-95. Directorate of Archaeology and Museums: Mysore.

DIKSHITAR, V.R.R.

1932 The Mauryan Polity. Madras: Madras Law Journal Press.

FALK, H.

1993 The art of writing at the time of the pillar edicts of Aśoka. Berliner Indologische Studien 7:79-102.

Fussman, G.

1987- Central and provincial administration in ancient India: The problem of the Mauryan 1988 empire. The Indian Historical Review 14:41-72.

GHosh, A., ED.

1990 An Encyclopedia of Indian Archaeology, vols. 1 and 2. New Delhi: E. J. Brill and Munshiram Manoharlal Publishers Pvt. Ltd.

НАвів, I., АND F. НАвів

1989- Mapping the Mauryan empire, in Proceedings of the Indian History Congress: Golden Jubilee 1990 Session: 57-79. Gorakhpur: Gorakhpur University.

Howell, J. R., G.V.S. Rao, J.V.P. Rao, and A. Howell

1995 Excavations at Sannathi 1986-1989. Memoirs of the Archaeological Survey of India no. 93. New Delhi.

Hultzsche, E.

1969 Inscriptions of Aśoka, new ed. Corpus Inscriptionum Indicarum, vol. 1. Oxford: Clarendon Press, for the Government of India. Reprint 1925, Delhi: Indological Bookhouse.

INDIAN ARCHAEOLOGY: A REVIEW

Volumes for 1962-63, 1963-64, 1966-67, 1968-69. New Delhi: Archaeological Survey of India.

KANGLE, R. P.

1965 The Kauţilīya Arthaśāstra Part III: A Study. Bombay: University of Bombay.

LAHIRI, N.

1992 The Archaeology of Indian Trade Routes. New Delhi: Oxford University Press.

Mishra, A. K.

1989 The Indian Black Wares: First Millennium B.c. Delhi: Pratibha Prakashan.

MORRISON, K.

1995 Trade, urbanism, and agricultural expansion: Buddhist monastic institutions and the state in the Early Historic western Deccan. World Archaeology 27(2):203-221.

2001 Sources, approaches, definitions, in Empires: 1-9, ed. S. Alcock et al. Cambridge: Cambridge University Press.

2002 E-mail, October.

Morrison, K., AND M. LyCett

1994 Centralized power, centralized authority? Ideological claims and archaeological patterns. Asian Perspectives 33(2):327-350.

Nagaraja Rao, M. S., and K. C. Malhotra

1965 The Stone Age Hill Duellers of Tekkalakota. Poona: Deccan College.

Nikam, N. A., And R. MCKeon

1959 The Edicts of Asoka. Chicago: University of Chicago Press.

Norman, K. R.

1980 The dialects in which the Buddha preached, in The Language of the Earliest Buddhist Tradition: 61-77, ed. H. Bechert. Gottingen: Vandenhoeck \& Ruprecht.

1991 Asokan inscriptions from Sannati. South Asian Studies 7:101-110.

Parasher, A.

1992 Nature of society and civilisation in early Deccan. The Indian Economic and Social History Revieul 29(4): 437-477.

Patil, C. S., and V. C. PATil, eds.

1998 Inscriptions of Raiclur District: Inscriptions of Karnataka, vol. 4. Mysore: Directorate of Archaeology and Museums. 
RAY, H. P.

1987 Early historical urbanization: The case of the western Deccan. World Archaeology 19(1): 94-104.

1989 Early historical trade: An overview. The Indian Economic and Social History Review 26(4) : 437-457.

1994 The Winds of Change: Buddhism and the Maritime Links of Early South Asia. Delhi: Oxford University Press.

Schwartzberg, J. E., eD.

1992 A Historical Atlas of South Asia. 2nd impression with additional material. New York: Oxford University Press.

SEN, A.

1956 Aśoka's Edicts. Calcutta: The Indian Publicity Society.

Seneviratne, S.

1978 The Mauryan State, in The Early State: 381-402, ed. H.J.M. Claasen and P. Skalnik. The Hague: Mouton.

1981 Kalinga and Andhra: The process of secondary state formation in early India. The Indian Historical Review 7(1-2):54-69.

SinOPOLI, C.

2001a Empires, in Archaeology at the Millennium: A Sourcebook: 439-471, ed. G. Feinman and T. Price. New York: Kluwer Academic/Plenum Publishers.

$2001 \mathrm{~b}$ On the edge of empire: Form and substance in the Sātavāhana dynasty, in Empires: 155-178, ed. S. Alcock et al. Cambridge: Cambridge University Press.

SIRCAR, D. C.

1979 Asokan Studies. Calcutta: Indian Museum.

SмITH, V. A.

1901 Asoka: The Buddhist Emperor of India. Oxford: Clarendon Press.

Sundara, A.

1986- Excavations at Sannati: 1986-87. Puratattva 17:22-25.

1987

ТАмвіан, S. J.

1976 World Conqueror and World Renouncer: A Study of Buddhism and Polity in Thailand against a Historical Background. New York: Cambridge University Press.

THAPAR, B. K.

1957 Maski 1954: A Chalcolithic site of the southern Deccan. Ancient India: Bulletin of the Archaeological Survey of India 13:4-142.

THAPAR, R.

1981 The state as empire, in The Study of the State: 410-426, ed. H.J.M. Claasen and P. Skalnik. The Hague: Mouton

1987 Towards the definition of an empire: The Mauryan State, in The Mauryas Revisited: 1-31. Calcutta: Centre for Studies in Social Sciences.

1997a Aśoka and the Decline of the Mauryas. Delhi: Oxford University Press.

1997 b Aśoka and Buddhism as reflected in the Aśokan edicts, in Aśoka 2300: Jagajjyoti: Aśoka Commemoration Volume 1997 A.D./2541 B.E.: 71-80, ed. H. B. Chowdhury. Calcutta: Bauddha Dharmankur Sabha.

Trautmann, T. R.

1971 Kautilya and the Arthasasastra: A Statistical Investigation of the Authorship and Evolution of the Text. Leiden: E. J. Brill.

WhEELER, R.E.M.

1947- Brahmagiri and Chandravalli 1947: Megalithic and other cultures in the Chitaldrug Dis1948 trict, Mysore State. Ancient India: Bulletin of the Archacological Survey of India 4:180-310.

1949 Archaeological fieldwork in India: Planning ahead. Ancient India 5:4-11.

\section{ABSTRACT}

The Aśokan edicts are a familiar and common form of archaeological and textual evidence frequently cited in discussions of the Mauryan polity. This paper is an 
attempt to move toward a more nuanced understanding of these inscriptions by examining earlier interpretations and previously held assumptions. One of the major assumptions questioned here is the way in which the edicts are frequently viewed as boundary markers of a uniformly administered empire.

The focus here is on the edicts found in the southern Deccan; a region whose actual relationship with the northern-based Mauryas is little understood but an area that is often assumed to have been incorporated into their empire. This interpretation is primarily supported by the presence of eleven rock edicts in the modern-day states of Karnataka and Andhra Pradesh. However, a closer look at the context, content, and composition of the edicts suggests that the relationship of this region to the Mauryan polity is not necessarily as clear-cut as previously believed. A structural loosening of the epistemological definition of empire has re-opened questions of what this relationship might have looked like and how it can be studied.

A critically refined analysis of the edicts is useful in providing a starting point to this inquiry, particularly by examining the question of meaning. By adopting the use of multidisciplinary perspectives, this paper argues that a simultaneous analysis of archaeological context, historical content, and linguistic composition is a useful strategy for examining issues of intended meaning and audience through the more specific problems of visibility, address, and comprehension. Keywords: Mauryas, Aśokan edicts, southern Deccan, empires. 